\title{
Isothermal, in vitro amplification of nucleic acids by a multienzyme reaction modeled after retroviral replication
}

\author{
(reverse transcriptase/RNase H/T7 RNA polymerase)
}

\author{
John C. Guatelli*†, Kristina M. Whitfield $\ddagger$, Deborah Y. KwoH ${ }^{\ddagger}$, KeVin J. Barringer $\ddagger$, \\ Douglas D. Richman*†, AND ThOMas R. Gingeras $¥ \S$
}

*Departments of Medicine and Pathology, University of California San Diego School of Medicine, and †'San Diego Veterans Administration Medical Center, San Diego, CA 92161; and †The Salk Institute Biotechnology/Industrial Associates, Inc., La Jolla, CA 92037

Communicated by Ronald M. Evans, December 18, 1989 (received for review October 6, 1989)

\begin{abstract}
A target nucleic acid sequence can be replicated (amplified) exponentially in vitro under isothermal conditions by using three enzymatic activities essential to retroviral replication: reverse transcriptase, RNase $H$, and a DNAdependent RNA polymerase. By mimicking the retroviral strategy of RNA replication by means of CDNA intermediates, this reaction accumulates CDNA and RNA copies of the original target. Product accumulation is exponential with respect to time, indicating that newly synthesized CDNAs and RNAs function as templates for a continuous series of transcription and reverse transcription reactions. Ten million-fold amplification occurs after a 1- to 2-hr incubation, with an initial rate of amplification of 10-fold every $2.5 \mathrm{~min}$. This self-sustained sequence replication system is useful for the detection and nucleotide sequence analysis of rare RNAs and DNAs. The analogy to aspects of retroviral replication is discussed.
\end{abstract}

The transfer of genetic information from RNA to DNA and then back to RNA is a scheme characteristic of retroviruses. Such a scheme provides a mechanism for the replication of RNA genomes (reviewed in refs. 1-3). In exploring variations of an in vitro transcription-based amplification system (TAS) (4), it was discovered that it was possible to devise a concerted, three-enzyme, in vitro reaction to carry out an isothermal replication of target nucleic acid sequences, analogous to the strategy used in retroviral replication. This reaction is a self-sustained sequence replication (3SR) system involving the collective activities of avian myeloblastosis virus (AMV) reverse transcriptase, Escherichia coli RNase $H$, and T7 RNA polymerase. The accumulation of both target nucleic acid-specific RNA and cDNA has been observed, quantitated, and characterized. Several aspects of this 3SR amplification protocol provide features not observed in the use of either the polymerase chain reaction or TAS protocols. These features and the parallels between the strategies employed in the 3SR reaction and during retroviral replication are noted and discussed.

\section{MATERIALS AND METHODS}

Materials. AMV reverse transcriptase was purchased from Life Sciences (Saint Petersburg, FL); T7 RNA polymerase was from Stratagene; $E$. coli $\mathrm{RNase} \mathrm{H}$ and RNase-free DNase I were from Bethesda Research Laboratories. Oligonucleotides were synthesized by phosphoramidate chemistry by using an Applied Biosystems model 380A DNA synthesizer. Trisacryl beads containing capture oligonucleotides, which were used for sandwich hybridizations, were prepared similarly to those described previously (5).

The publication costs of this article were defrayed in part by page charge payment. This article must therefore be hereby marked "advertisement" in accordance with $18 \mathrm{U}$ U.S.C. $\$ 1734$ solely to indicate this fact.
RNA Purification. Human immunodeficiency virus type 1 (HIV-1) RNA was extracted in total RNA from HIV1-infected CEM cells by the guanidinium isothiocyanate/ cesium chloride gradient procedure (6) and quantitated by comparative hybridization to standards of known concentration.

3SR Reaction. One hundred-microliter 3SR amplification reactions contained the target $\mathrm{RNA}, \mathbf{4 0} \mathrm{mM}$ Tris $\cdot \mathrm{HCl}$ at $\mathbf{p H}$ $8.1,20 \mathrm{mM} \mathrm{MgCl}_{2}, 25 \mathrm{mM} \mathrm{NaCl}, 2 \mathrm{mM}$ spermidine hydrochloride, $5 \mathrm{mM}$ dithiothreitol, bovine serum albumin (80 $\mu \mathrm{g} / \mathrm{ml}), 1 \mathrm{mM}$ dATP, $1 \mathrm{mM}$ dCTP, $1 \mathrm{mM}$ dGTP, $1 \mathrm{mM}$ dTTP, $4 \mathrm{mM}$ ATP, $4 \mathrm{mM}$ CTP, $4 \mathrm{mM}$ GTP, $4 \mathrm{mM}$ UTP, $250 \mathrm{ng}$ of oligonucleotide 88-211 (primer B, 5'-AATTTAATACGACTCACTATAGGGATCTATTGTGCCCCGGCTGGTTTTGCGATTCTA-3'), and 250 ng of oligonucleotide 88-347 (primer A, 5'-AATTTAATACGACTCACTATAGGGATGTACTATTATGGTTTTAGCATTGTCTAGTGA-3'). [Each priming oligonucleotide contains the T7 RNA polymerase binding sequence (italic) and the preferred transcriptional initiation site (boldface). The remaining sequence is complementary to the target HIV-1 sequence.] After heating at $65^{\circ} \mathrm{C}$ for $1 \mathrm{~min}$ and cooling at $37^{\circ} \mathrm{C}$ for $2 \mathrm{~min}, 30$ units of AMV reverse transcriptase, 100 units of T7 RNA polymerase, and 4 units of $E$. coli $\mathrm{RNase} \mathrm{H}$ were added to each reaction. All reactions were incubated at $37^{\circ} \mathrm{C}$ for $1 \mathrm{hr}$ or the amount of time indicated and stopped by placing the reaction on ice.

Bead-Based Sandwich Hybridization. The 3SR amplification product and ${ }^{32} \mathrm{P}$-labeled oligonucleotide 87-81 (5'AATTAGGCCAGTAGTATCAACTCAACT-3') were denatured in $30 \mu \mathrm{l}$ of $10 \mathrm{mM}$ Tris, $\mathrm{pH} \mathrm{8.1/1} \mathrm{mM} \mathrm{EDTA} \mathrm{at} 65^{\circ} \mathrm{C}$ for $5 \mathrm{~min}$ in an Eppendorf tube. To this, $30 \mu \mathrm{l}$ of a solution hybridization mixture [10 $\times$ standard saline phosphate/EDTA (6) $/ 10 \%$ (wt/vol) dextran sulfate/0.2\% SDS] was added. The solution was mixed and incubated at $42^{\circ} \mathrm{C}$ for $2 \mathrm{hr}$.

Approximately $25 \mathrm{mg}$ (wet weight) of Trisacryl beads containing oligonucleotide 86-273 (5'-AGTCTAGCAGAAGAAGAGGTAGTAATTAGA-3') was prehybridized in 250 $\mu$ l of hybridization solution ( $5 \times$ standard saline phosphate/ EDTA $/ 10 \%$ dextran sulfate/0.1\% SDS) in a 2-ml microcolumn (Isolab) for $30 \mathrm{~min}$ at $37^{\circ} \mathrm{C}$. The prehybridization solution was removed, and $40 \mu$ l of fresh hybridization solution was added to the beads, together with the $60 \mu$ l of solution from the solution hybridization step. The beads were then incubated at $37^{\circ} \mathrm{C}$ for $1 \mathrm{hr}$ with occasional mixing and then washed six times with $1 \mathrm{ml}$ of $2 \times$ standard saline citrate (6) at $37^{\circ} \mathrm{C}$. The radioactivity of the beads and the combined washes was measured by Cerenkov counting for $1 \mathrm{~min}$. The amount of target detected was determined by calculating the percentage of total radioactivity captured on the beads and

Abbreviations: 3SR, self-sustained sequence replication; TAS, transcription-based amplification system; HIV-1, human immunodeficiency virus type 1 ; AMV, avian myeloblastosis virus.

$\S$ To whom reprint requests should be addressed. 
then multiplying this percentage by the femtomoles of ${ }^{32} \mathrm{P}$ labeled oligonucleotides used for the hybridization.

Nuclease Digestion. Samples of 3SR reactions were digested with RNase-free DNase $I$ in $50 \mathrm{mM}$ sodium acetate at pH $6.5,10 \mathrm{mM} \mathrm{MgCl}_{2}$, and $2 \mathrm{mM} \mathrm{CaCl}_{2}$ in the presence of enzyme $(25 \mu \mathrm{g} / \mathrm{ml})$ at $37^{\circ} \mathrm{C}$ for $1 \mathrm{hr}$. Digestions were terminated by the addition of EDTA to $12.5 \mathrm{mM}$ and were extracted once with an equal volume of phenol/chloroform prior to separation in a $5 \%$ denaturing polyacrylamide gel.

Direct 3SR Transcript Sequencing. One hundred-microliter 3SR reactions were extracted once with an equal volume of phenol/chloroform, adjusted to $0.3 \mathrm{M}$ sodium acetate, and precipitated with the addition of 2.5 volumes of $100 \%$ ethanol. The reaction products were pelleted at $16,000 \times g$ for 10 min, rinsed with $70 \%$ (vol/vol) ethanol, and dried completely before being dissolved in $50 \mu \mathrm{l}$ of sterile $\mathrm{H}_{2} \mathrm{O}$. Two percent of the transcript (derived from a $10^{7}$-fold amplification from $100 \mathrm{amol}$ of target HIV) was sequenced (7) by using a primer complementary to the major antisense 3SR RNA product and located within the targeted $e n v$ region (5'-GACGTTCAATGGAAC-3').

cDNA Cloning and Sequencing. The 3SR reactions were extracted once with phenol/chloroform, precipitated with ethanol, and converted into first- and second-strand cDNAs by the single-tube method first described by D'Alessio and Gerard (8). The second-strand synthesis reaction was terminated by heating, and the cDNA ends were repaired by the direct addition of 20 units of the large fragment of $E$. coli DNA polymerase I, followed by a $1.5-\mathrm{hr}$ incubation at $22^{\circ} \mathrm{C}$. End-repaired cDNAs were extracted once with one volume of phenol/chloroform and then precipitated (in the presence of $10 \mu \mathrm{g}$ of glycogen as a carrier) with 3 volumes of $100 \%$ ethanol. Precipitated cDNAs were phosphorylated with T4 polynucleotide kinase (6), ligated into pUC19 that had been cut with Sma I and treated with phosphatase, and used to transform $E$. coli strain MC1061. 3SR clone-containing transformants were identified by colony hybridization by using a kinased oligonucleotide probe. Clones were sequenced with a Sequenase dideoxy sequencing kit according to the manufacturer's directions (United States Biochemical).

\section{RESULTS}

3SR Strategy and Kinetics of Amplification. The strategy for RNA replication by the 3SR reaction is depicted in Fig. 1. In summary, a continuous series of reverse transcription and transcription reactions replicates an RNA target sequence by means of cDNA intermediates. The crucial elements of this design are $(i)$ as with the TAS protocol, the oligonucleotide primers both specify the target and contain $5^{\prime}$ extensions encoding the T7 RNA polymerase binding site, so that the resultant cDNAs are competent transcription templates (4); (ii) cDNA synthesis can proceed to completion of both strands due to the degradation of RNA in the intermediate RNA.DNA hybrid by $\mathrm{RNase} \mathrm{H}$; and (iii) the reaction products (cDNA and RNA) can function as templates for subsequent steps, enabling exponential replication. During the initial stage, the 3SR reaction proceeds first to the formation of antisense RNA, as drawn in Fig. 1. This pathway is attributable to the lack of a double-stranded DNA structure for the T7 promoter, which would produce a sense RNA transcript (Fig. 1, step 6). This situation predicts the production of antisense RNA as the favored product in the initial cycle of a 3SR reaction in which two $\mathrm{T} 7$ promoters are used.

Such a 3SR strategy has been applied to the amplification of a 214-nucleotide region of the envelope gene (env) of HIV-1, measured by using a bead-based sandwich hybridization system, which detects and quantitates the singlestranded RNA copies specific for this region of env (9). Amounts of HIV-1 RNA from $10^{-5}$ to $10^{-1} \mathrm{fmol}$ were

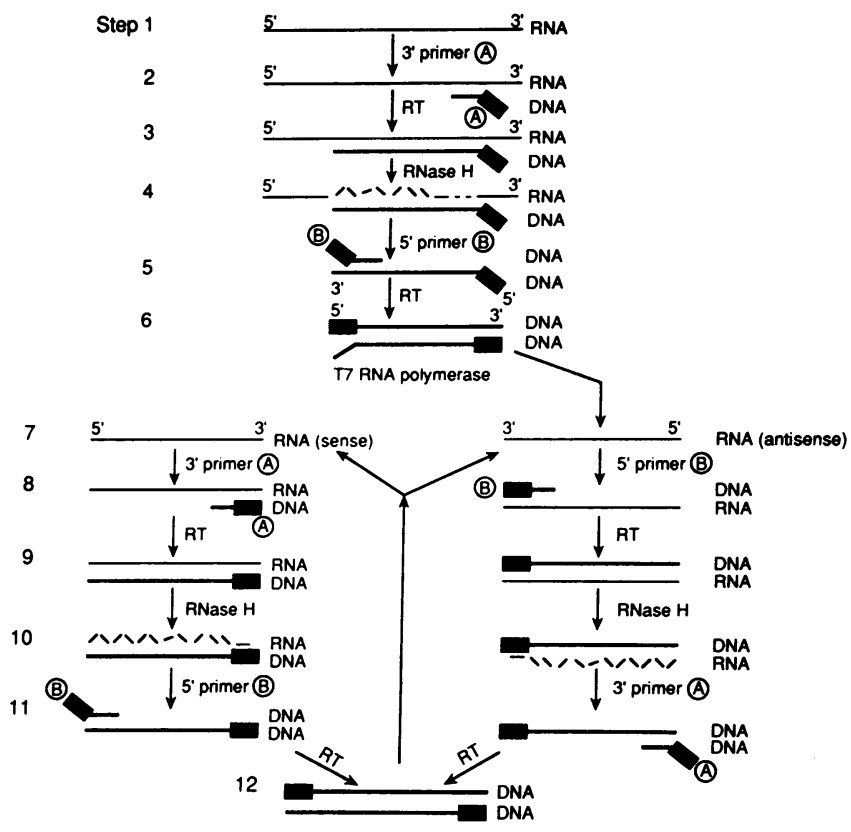

FIG. 1. Strategy of the 3SR scheme. The 3SR reaction depends on a continuous cycle of reverse transcription and transcription reactions to replicate an RNA target by means of cDNA intermediates. Oligonucleotides $A$ and $B$ prime DNA synthesis and encode the promoter sequence for the T7 RNA polymerase (black boxes). Steps 1-6 depict the synthesis of a double-stranded cDNA, which is a transcription template for T7 RNA polymerase. Complete cDNA synthesis is dependent on the digestion of the RNA in the intermediate RNA.DNA hybrid (step 4) by RNase H. Transcriptioncompetent cDNAs yield antisense RNA copies of the original target (step 7, right). These transcripts are converted to cDNAs containing double-stranded promoters on both ends in an inverted repeat orientation (steps 7-12). These cDNAs can yield either sense or antisense RNAs, which can reenter the cycle. Thin lines, RNA; thick lines, DNA; RT, reverse transcription.

replicated in a $2-\mathrm{hr} 3 \mathrm{SR}$ reaction, and the 3SR RNA products were measured by bead-based sandwich hybridization system as a function of time (Fig. $2 A$ ). Within the first $15 \mathrm{~min}$, each of the input HIV-1 RNA target concentrations was increased $10^{5}$-fold, followed by a 90 -fold increase over the next $105 \mathrm{~min}$. Interestingly, during the first $10 \mathrm{~min}$ (Fig. $2 \mathrm{~A}$ Inset), the amount of $3 S R$ RNA products increased $\approx 10$-fold every $2.5 \mathrm{~min}$. The slower rate of replication observed after the first $10 \mathrm{~min}$ does not appear to be attributable to the accumulation of target-specific products of the reaction, since the rate of amplification decreased at the same time for all initial target concentrations. The initial exponential rate of increase in the copy number of this env region is consistent with a repeated cycling mechanism for the 3SR reaction in which the products function as templates, as predicted in Fig. 1. In addition, the reported (10) maximal initiation rate of the T7 RNA polymerase ( 0.8 initiation per second per template) appears to be too slow to produce the levels of RNA product observed within the first $15 \mathrm{~min}$ of the $3 \mathrm{SR}$ reaction in the absence of an increase in the number of templates during the reaction. The efficiency of the $3 S R$ reaction is affected only slightly by the initial concentration of HIV-1 RNA, as is observed when $3 \times 10^{6}$ - and $9 \times 10^{6}$-fold amplifications were produced from $10^{-1}$ and $10^{-5}$ fmol of input target HIV-1 RNA, respectively.

Characterization of 3SR Amplification Products. This selfsustained cyclical reaction predicts the accumulation of RNA products, principally due to the efficiency of the transcription steps, but also due to single- and double-stranded DNA copies of the original target RNA sequence. The cDNA products of the $3 S R$ reaction have been characterized (Fig. 
A

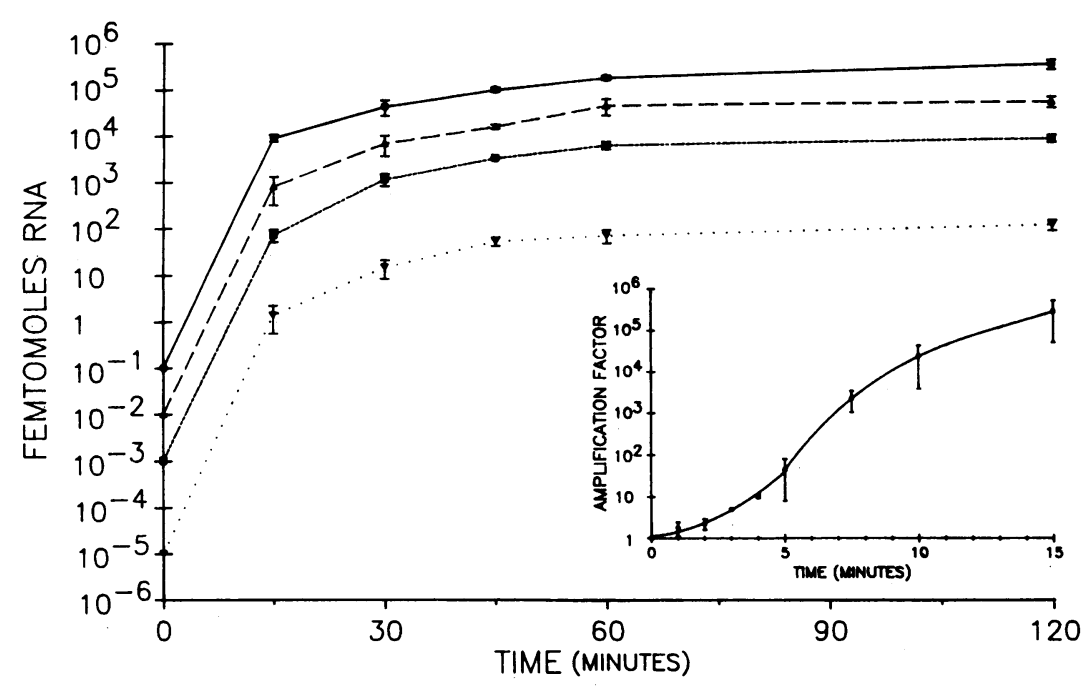

B

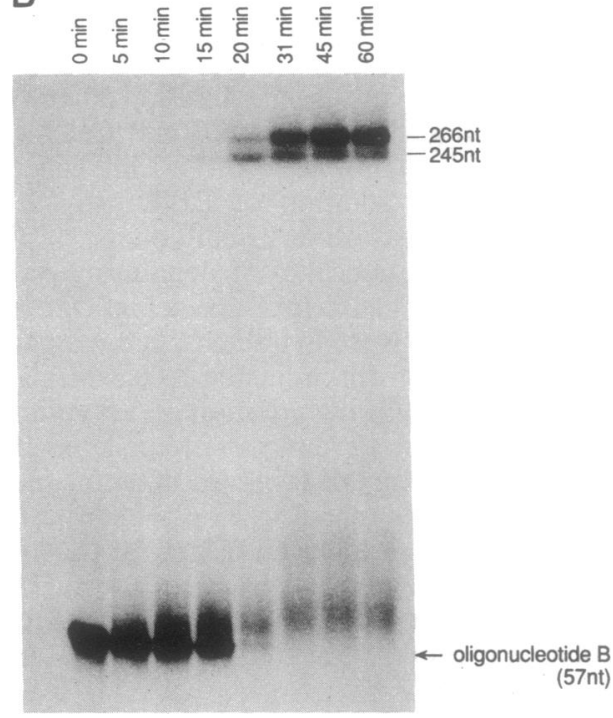

Fig. 2. Accumulation and quantitation of RNA and cDNA products of 3SR reactions over time. (A) The kinetics of antisense RNA accumulation is demonstrated as measured by a bead-based sandwich hybridization system. Each point represents the average of four experiments, and the standard deviation is illustrated by the error bars. The input target, sense RNA, was quantitated by comparative hybridization with HIV-1 sequences, which was quantitated spectrophotometrically. (Inset) Results obtained from two 3SR reactions; the starting HIV-1 target RNA concentration was 1 fmol for time points of 1-5 min and 0.1 fmol for 5-15 min. The fold amplification presented at each time point is the average of 2-4 experiments. $(B)$ The accumulation with time of labeled cDNA products containing either one promoter ( 245 base pairs) or two promoters (266 base pairs) in a 3SR reaction is shown. The reaction was initiated with 50 amol of HIV-1 RNA as the target, with $250 \mathrm{ng}$ of ${ }^{32} \mathrm{P}$-end-labeled oligonucleotide 88-211 (primer B) and $250 \mathrm{ng}$ of unlabeled oligonucleotide 88-347 (primer A) as the primers. The products were electrophoresed on a $6 \%$ denaturing polyacrylamide gel. The 245- and 266-base-pair bands from the 31-min reaction were excised, the amount of radioactivity incorporated was assayed, and the amount of labeled cDNA was calculated to be $\approx 5$ pmol. nt, Nucleotides.

$2 B)$. cDNAs of a prescribed length, as defined by the positions of two primers, accumulate throughout the course of the reaction. When two primers containing $\mathrm{T} 7$ promoters were used in amplifying 50 amol of HIV-1 RNA and one of the 3SR primers (primer B) was end-labeled with ${ }^{32} \mathrm{P}$, the CDNA products observed were 245 (214-base HIV sequence + 27-base T7 sequence + 4-base transcription start sequence) and 266 (same as 245 -base product +21 -base $T 7$ sequence) bases in length (Fig. $2 B$ ). The 245-base cDNA presumably results from the extension of primer $B$ on an antisense transcript [Fig. 1, step 9 (antisense)]. After degradation of the RNA in the RNA.DNA hybrid and the subsequent annealing of primer A, the cDNA can extend to the full 266-base length (Fig. 1, step 12).

An estimate of the average transcriptional efficiency of the 3SR reaction can be made by comparing the amplification of RNA to that of DNA. When the CDNA products containing one or two $\mathrm{T} 7$ promoters were excised from the polyacrylamide gel, the amount of radioactivity incorporated was assayed (Fig. $2 B$ ), and the amount of amplification was calculated by using the specific activity of the ${ }^{32} \mathrm{P}$-labeled primers, at least $10^{5}$-fold cDNA amplification could be measured as a result of these reactions. When compared to the 9 $\times 10^{6}$-fold levels of RNA produced from the same type of reaction, this productivity in the yield of CDNA indicates that, on the average, each cDNA template directs the synthesis of a minimum of 90 copies of detectable RNA during the 3 SR reaction.

The RNA products from the 3SR reactions have been analyzed. In the case of the amplification of the 214nucleotide region of the HIV-1 env gene, DNase digestion of the 3SR reaction products revealed antisense RNA that is 245 nucleotides in length (Fig. $3 A$ ). Full-length RNA products from these 3SR reactions contain the sequences complementary to the $\mathrm{T} 7$ promoter sequence at the $3^{\prime}$ end of the transcript (Fig. 1), so that the 245 nucleotides represent the combined lengths of the HIV-1 (214 nucleotides), T7 (27 nucleotides), and transcription start (4 nucleotides) se- quences (Fig. 3A). Numerous RNA products were also observed that were less than full length but hybridized with the HIV-1 env-specific probe. The fidelity of synthesis of these product RNAs to the original target sequence was partially verified by a direct sequencing reaction (7) using a ${ }^{32}$ P-labeled internal primer (Fig. 3B), which yielded the expected sequence from the HIV-1 env region (9). Interestingly, when a ${ }^{32} \mathrm{P}$-labeled probe specific for the detection of

$$
\text { A }
$$

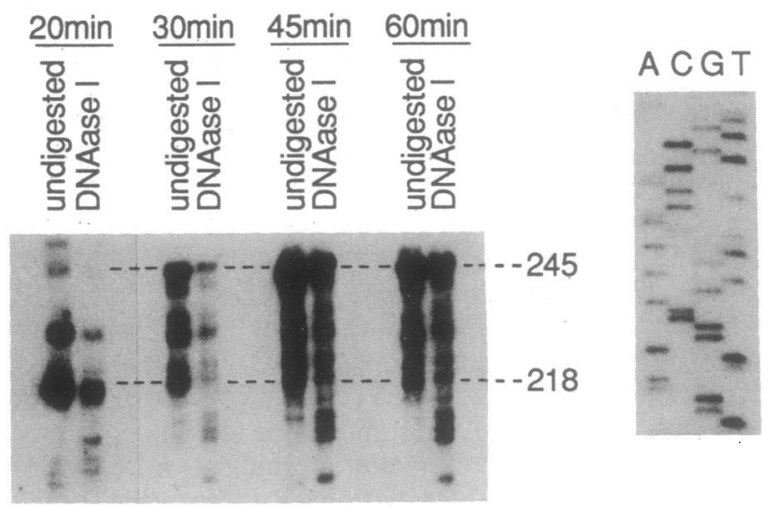

FIG. 3. Characterization of 3SR RNA and DNA products by Southern hybridization and nucleotide sequencing. $(A)$ An autoradiograph of a $5 \%$ denaturing polyacrylamide gel shows the results of a $3 S R$ reaction after $20,30,45$, and $60 \mathrm{~min}$ into the reaction, before and after digestion with DNase I. Digested and undigested products were analyzed by Southern blot analysis (6) using oligonucleotide 88-298 as the labeled probe (5'-ACAGTACAATGTACACATGGAATTAGGCCA-3'). Sizes of the bands (in nucleotides) are indicated. (B) Direct sequencing (7) of the antisense RNA transcript from a 3SR reaction. The portion shown reads 5'-TGGAATTAGGCCAGTAGTATCAACTCAACTGCTGTTAAA-3' and is the exact match for the HIV-1 sequence described by Ratner et al. (9) from residues 6548 to 6586 . 
sense-strand RNA was used in a hybridization, 100-fold less sense-strand RNA was detected than antisense RNA (data not shown). The mechanism by which one promoter assumes the greatest production of RNA is partially explained by measuring the transcriptional efficiency of each promoter independently. The results of this measurement indicated an 8-fold difference in the ability of the two promoters to produce RNA transcripts from this region, in favor of the antisense $\mathrm{T} 7$ promoter (data not shown).

Nucleotide sequence characterization of the products of a 3SR reaction reveals truncated products. Ten individual clones derived from the RNA and CDNA of this reaction have been analyzed, and they contain both complete and truncated forms of the predicted sequence (Fig. $4 A$ ). Three of these clones $(97,116$, and 125$)$ appear capable of perpetuating the cycle of 3SR replication. Although it is not possible to determine the degree to which these truncations resulted from cloning artifacts versus the amplification process, such shorter products are seen in Fig. 3. Two variations in the sequence of the 3SR clones (121 and 128) are noted when compared to the original HIV-1 sequence of this region. Such variations from the parent sequence are presumably the result of the mismatch error properties of both the reverse transcriptase and $\mathrm{T} 7$ polymerase.

Influence of $E$. coli RNase $H$ on RNA Products of 3SR. RNA products that are less than full length appear to result, at least in part, from $\mathrm{RNase} H$ degradation during the $3 \mathrm{SR}$ reaction. When products from a 60 -min 3SR reaction were reincubated with $\alpha$-labeled CTP and T7 RNA polymerase and chased with unlabeled CTP, then RNA that was 245 nucleotides in length (full length, including a T7 promoter complementary sequence at the $3^{\prime}$ end) was produced (Fig. $4 B$ ). If the products were reincubated with $T 7$ polymerase and $E$. coli RNase $H$, a truncated RNA of $\approx 200$ nucleotides was produced. The truncated RNA presumably results from degradation of the $3^{\prime}$ end of the molecule; when annealed to the DNA oligonucleotide primer, a substrate for RNase H (RNA.DNA hybrid) is formed. Curiously, the entire length of this RNA.DNA duplex was not degraded; if it were, the RNA molecule would be rendered unusable as a template for subsequent cDNA synthesis.

The concept that many 3SR RNA products have end truncations that delete primer-complementary sequences is supported by a comparison of Figs. $3 A$ and $2 B$. RNA products detected by hybridization with an internal probe (Fig. $3 A$ ) revealed several species of short products, which may represent both incomplete transcripts as well as degradation products.

\section{DISCUSSION}

As a practical amplification strategy, the $3 \mathrm{SR}$ protocol is suited to the specific detection and quantification of RNA

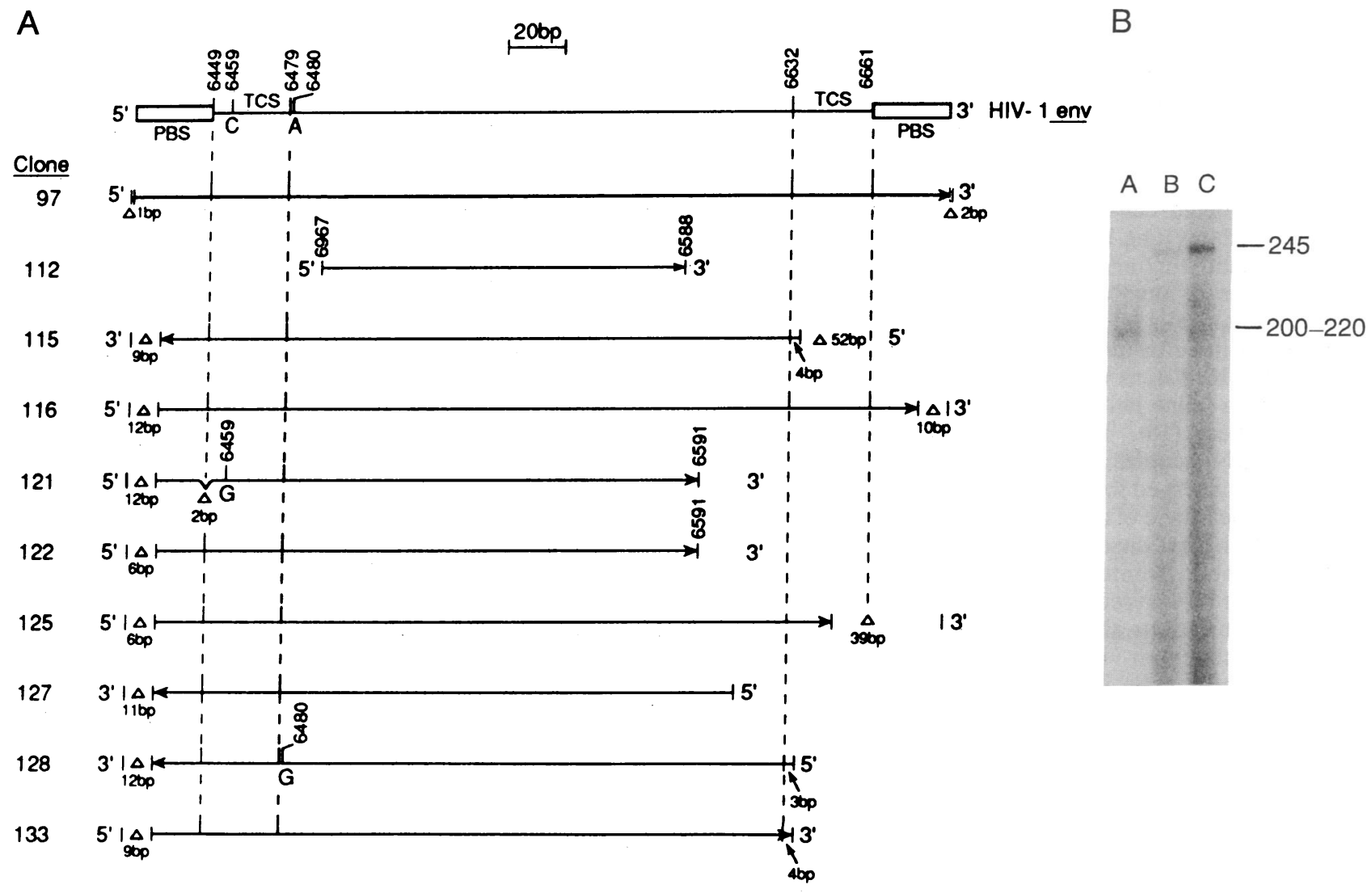

FIG. 4. The effect of $E$. coli $\mathrm{RNase} H$ during a 3SR reaction and nucleotide sequence analysis of cloned 3 SR products. $(A) A$ map of 10 isolated and sequenced cDNA clones derived from a 60-min 3SR reaction is illustrated. The targeted portion of the HIV-1 env region is shown at the top of the figure (9). The env region is demarked by primers 88-211 and 88-347, each of which contains 27 base pairs (bp) of a consensus T7 RNA polymerase binding sequence (PBS), and the corresponding target-complementary sequences (TCS). Differences between the cloned sequences and the published sequences are indicated. (B) Products of a 60-min 3SR reaction (0.1 pmol), which amplified $10^{7}$-fold (from 0.1 amol), were reincubated in 3SR buffer containing $0.5 \mathrm{mM} \mathrm{GTP}, 0.5 \mathrm{mM}$ ATP, $0.5 \mathrm{mM}$ UTP, $6 \mu \mathrm{M}$ unlabeled CTP, $10 \mu \mathrm{Ci}$ of $\left[\alpha-{ }^{32} \mathrm{P}\right] \mathrm{CTP}(800 \mathrm{Ci} / \mathrm{mmol}$; $1 \mathrm{Ci}=37 \mathrm{GBq}$ ) as well as $0.5 \mathrm{mM}$ dATP, $0.5 \mathrm{mM}$ dGTP, $0.5 \mathrm{mM} \mathrm{dTTP}$, and $0.5 \mathrm{mM} \mathrm{dCTP}$. The reactions were heated to $65^{\circ} \mathrm{C}$ for $1 \mathrm{~min}$ and cooled to $37^{\circ} \mathrm{C}$ for 1 min prior to the addition of 100 units of T7 RNA polymerase and 4 units of $E$. coli RNase $\mathrm{H}$ (lane A), 30 units of AMV reverse transcriptase and 100 units of T7 RNA polymerase (lane B), or 100 units of T7 RNA polymerase (lane C). The reactions were incubated for $15 \mathrm{~min}$ at $37^{\circ} \mathrm{C}$, followed by the addition of $0.1 \mathrm{nmol}$ of unlabeled CTP, with continued incubation at $37^{\circ} \mathrm{C}$ for another $15 \mathrm{~min}$. After removal of the unincorporated label, $1 \%$ of the reaction was resolved on a $6 \%$ denaturing polyacrylamide gel before autoradiography. Sizes of the bands (in base pairs) are indicated. 
sequences. The in vitro $3 \mathrm{SR}$ reaction operates at $37^{\circ} \mathrm{C}$ and, consequently, temperatures required to denature doublestranded DNA are not employed, unlike both the TAS (4) and polymerase chain reaction (11) protocols. Under these conditions, double-stranded DNAs would fail to function as amplification templates, rendering 3SR ideal for assessing the transcriptional activity of specific genes. However, DNA templates have been amplified by using this 3SR reaction, with efficiencies equivalent to those observed for RNA templates (data not shown) by the inclusion of a denaturation step at the outset of the protocol. A second feature of the 3SR reaction distinct from the well-used polymerase chain reaction protocol is the rapid kinetics observed in the 3SR reaction. To achieve the $10^{5}$-fold amplification observed in the first $15 \mathrm{~min}$ of the $3 \mathrm{SR}$ reaction, a polymerase chain reaction would require $85 \mathrm{~min}$, even if one assumes a percycle time of $5 \mathrm{~min}$ and a per-cycle efficiency of $100 \%$.

Also of practical importance is the finding that 3SR can operate effectively if only one primer contains the $\mathrm{T} 7$ promoter (data not shown). The effectiveness of 3SR reactions employing only one primer encoding the $\mathrm{T} 7$ promoter indicates that, in contrast to the genomic RNA of retroviruses, it is not necessary for 3SR RNA products to encode a promoter sequence on their $3^{\prime}$ ends. This $3^{\prime}$ RNA structure is required for retroviral replication in order to solve the problem of promoter-sequence loss during transcription (12). In the 3SR reaction, this RNA structure is unnecessary because the primers themselves bring the promoter sequence into the cDNA molecule.

The in vitro exponential amplification of a region of the HIV-1 genome using three enzymatic activities that are found in all cells infected with retroviruses suggests that the accumulation of multiple viral DNA copies found in such cells may be due to an intracellular, 3SR-like mechanism. In chronically infected cells and biopsied lymph node tissue, HIV-1 accumulates long-lived, unintegrated, viral DNA copies, predominantly in linear forms (13). The presence of such multiple copies of unintegrated viral DNA has also been reported in duck cells infected in vitro with B77 (14), spleen necrosis virus-infected avian cells (15), avian leukosis virusinfected cells $(16,17)$, as well as in bone marrow cells of cats infected with a feline leukemia virus variant that causes an AIDS-like illness (18). The accumulation of such unintegrated viral DNA copies has been correlated with the cytopathic effects observed for avian leukosis virus (16); in feline AIDS, the appearance of a variant form of unintegrated DNA correlates with the onset of disease (18). The origin of high-copy-number, unintegrated viral DNA is unknown, but viral DNA can be derived from either multiple infections of the same host cell or the reverse transcription of newly transcribed, full-length viral RNA. The multiple reinfection of the same host cells is an unlikely explanation for the accumulation of HIV-1 viral DNA in vivo because of the low number of cells infected and their low level of RNA expression (19). Intracellular cycles of reverse transcription and transcription, however, could result in viral DNA accumulation, even with low-level RNA expression, by means of the process exemplified by the in vitro 3SR reaction.

The parallel between the in vitro $3 \mathrm{SR}$ reaction and the production of viral DNA also opens to speculation the role of RNase $H$ in both of these systems. Retroviral RNase $H$ is considered to be the enzyme responsible for the digestion of RNA.DNA hybrids, so that second-strand cDNA synthesis can occur. For murine leukemia virus, replication is dependent on reverse transcriptase-associated RNase $H$ (20). Yet, neither AMV nor murine leukemia virus $R N a s e ~ H$ can efficiently catalyze the $3 S R$ reaction without supplementation by $E$. coli RNase H (data not shown). Traditionally, retroviral $\mathrm{RNase} H$ has been believed to be a processive exonuclease, requiring free ends (21-23), although recent evidence suggests endoribonuclease activity as well (24). $E$. coli $\mathrm{RNase} \mathrm{H}$ is an endoribonuclease (25). By analogy to the $E$. coli $\mathrm{RNase} \mathrm{H}$ dependency of $3 \mathrm{SR}$, it is interesting to speculate on the role that the host-cell $R$ Nase $H$, an endoribonuclease like that of $E$. coli $(22)$, may play in retroviral replication.

The early evolution of reverse transcriptase activity has been proposed as an important event during the transition from an early-RNA to present-day DNA world (26). The coupling of reverse transcription to transcription creates a system for information transfer between two classes of macromolecules, RNA and DNA. The ease with which the repetitive cycling of this process can occur in vitro, catalyzed by only three enzymes, suggests that it may have played an early role in the evolution of nucleic acid replication strategies.

We thank A. W. McCue and N. Riggs for their technical assistance, L. Blonski and C. Lynch for the synthesis and purification of the oligonucleotides used, and J. Doty for her careful preparation of this manuscript. This work was supported in part by Public Health Service Grants HB-67019, AI52578, and NIH 5-T32-AI07036 from the National Institutes of Health and by the Veterans Administration (D.D.R.) and the Salk Institute Biotechnology/Industrial Associates, Inc. (T.R.G.).

1. Varmus, H. E. \& Swanstrom, R. (1984) in RNA Tumor Viruses, eds. Weiss, R., Teich, N., Varmus, H. \& Coffin, J. (Cold Spring Harbor Laboratory, Cold Spring Harbor, NY), Vol. 1, pp. 369-512.

2. Varmus, H. E. \& Swanstrom, R. (1984) in RNA Tumor Viruses, eds. Weiss, R., Teich, N., Varmus, H. \& Coffin, J. (Cold Spring Harbor Laboratory, Cold Spring Harbor, NY), Vol. 2, pp. 75-185.

3. Varmus, H. E. (1988) Science 240, 1427-1435.

4. Kwoh, D. Y., Davis, G. R., Whitfield, K. M., Chappelle, H., DiMichele, L. \& Gingeras, T. R. (1989) Proc. Natl. Acad. Sci. USA 86, 1173-1177.

5. Ghosh, S. S. \& Musso, G. F. (1987) Nucleic Acids Res. 15, 53535372.

6. Maniatis, T., Fritsch, E. F. \& Sambrook, J. (1982) Molecular Cloning: A Laboratory Manual (Cold Spring Harbor Laboratory, Cold Spring Harbor, NY).

7. Stoflet, E. S., Koeberl, D. D., Sarkar, G. \& Sommer, S. S. (1988) Science 239, 491-494.

8. D'Alessio, J. M. \& Gerard, G. F. (1988) Nucleic Acids Res. 16, 1999-2014.

9. Ratner, L., Haseltine, W., Patarca, R., Livak, K. J., Starcich, B., Josephs, S. F., Doran, E. R., Rafalski, J. A., Whitehorn, E. A., Baumeister, K., Ivanoff, L., Petteway, S. R., Pearson, M. L., Lautenberger, J. A., Papas, T. S., Ghrayeb, J., Chang, N. T., Gallo, R. C. \& Wong-Staal, F. (1985) Nature (London) 313, 277284.

10. Martin, C. T. \& Coleman, J. E. (1987) Biochemistry 26, 2690-2696.

11. Saiki, R. K., Scharf, S., Faloona, F., Mullis, K. B., Horn, G. T., Erlich, H. A. \& Arnheim, N. (1985) Science 230, 1350-1354.

12. Gilboa, E., Mitra, S. W., Goff, S. \& Baltimore, D. (1979) Cell 18, 93-100.

13. Shaw, G. M., Hahn, B. H., Arya, S. K., Groopman, J. E., Gallo, R. C. \& Wong-Staal, F. (1984) Science 226, 1165-1171.

14. Varmus, H. E. \& Shank, P. R. (1976) J. Virol. 18, 567-573.

15. Keshet, E. \& Temin, H. M. (1979) J. Virol. 31, 376-388.

16. Weller, S. K. \& Temin, H. M. (1981) J. Virol. 39, 713-721.

17. Weller, S. K., Joy, A. E. \& Temin, H. M. (1980) J. Virol. 33, 494-506.

18. Mullins, J. I., Chen, C. S. \& Hoover, E. A. (1986) Nature (London) 319, 333-336.

19. Harper, M. E., Marselle, L. M., Gallo, R. C. \& Wong-Staal, F. (1986) Proc. Natl. Acad. Sci. USA 83, 772-776.

20. Repaske, R., Hartley, J. W., Kavlick, M. F., O'Neill, R. R. \& Austin, J. B. (1989) J. Virol. 63, 1460-1464.

21. Grandgenett, D. P. \& Green, M. (1974) J. Biol. Chem. 249, 51485152.

22. Keller, W. \& Crouch, R. (1972) Proc. Natl. Acad. Sci. USA 69, 3360-3364.

23. Verma, I. M. (1975) J. Virol. 15, 843-854.

24. Krug, M. S. \& Berger, S. L. (1989) Proc. Natl. Acad. Sci. USA 86, 3539-3543.

25. Leis, J. P., Berkower, I. \& Harwitz, J. (1973) Proc. Natl. Acad. Sci. USA 70, 466-470.

26. Varmus, H. E. (1989) Cell 56, 721-724. 